\title{
Pengaruh Berbagai Tingkat Penggunaan Ampas Ganyong (Canna edulis Kerr) dalam Ransum terhadap Fermentabilitas dan Kecernaan (In Vitro)
}

\author{
A. R. Widiyanti, E. Cardi, U. H. Tanuwiria, A. R. Tarmidi, \& I. Hernaman* \\ Departemen Nutrisi Ternak dan Teknologi Pakan Fakultas Peternakan Universitas Padjadjaran \\ Jl. Raya Bandung-Sumedang Km 21 Jatinangor Sumedang 45363 \\ *Email : iman.hernaman@unpad.ac.id \\ (Diterima : 20 Maret 2020; Disetujui : 22 April 2020)
}

\begin{abstract}
Canna waste is the processing waste of canna tubers into flour. This feed ingredient has potential as ruminant feed. The research aims to evaluate the use of canna waste in rations in vitro. The study used a completely randomized design with 4 treatments and 5 replications. The treatments were rations containing $0 \%(R 0), 10 \%(R 1), 20 \%(R 2)$ and $30 \%$ (R3) canna waste. The resulting data were analyzed by Duncan's test. The use of canna waste did not have a significant effect on the production of $N$-NH, but caused a decrease $(P<0.05)$ on volatile fatty acids, dry matter digestibility and organic matter digestibility. Rations containing more than $20 \%$ of canna's waste cause volatile fatty acids below the normal range and digestibility of dry matter $<50 \%$. The relationship between volatile fatty acids with dry matter digestibility and organic matter digestibility shows a linear line equation, namely: $y=0.1459 x+$ 34.7779 with $R^{2}=0.8278, r=0.9098$ and $y=0.1159 x+40.794$ with $R^{2}=0.7978, r=0.8931$. The results of the study concluded that the use of canna waste in the ration was a maximum of $10 \%$.
\end{abstract}

Keywords: canna (Canna edulis Kerr.) waste, digestibility, fermentability, in vitro, ruminants.

\section{PENDAHULUAN}

Pada dasarnya kebutuhan pakan bagi ternak ruminansia berfungsi sebagai komponen utama dalam pemenuhan kebutuhan hidup pokok dan produksi. Namun ketersediaannya terbatas pada musim kemarau yang akan menjadi kendala dalam peningkatan produksi ternak ruminansia. Oleh karena itu, perlu dilakukan pencarian bahan pakan alternatif. Salah satunya adalah pemanfaatan hasil samping atau limbah dari pengolahan hasil pertanian. Pemanfaatan limbah pertanian selain untuk mendaur ulang biomassa, juga mengurangi pencemaran di lokasi produksi.

Ganyong adalah tanaman pertanian dengan hasil utama berupa umbi. Ganyong banyak digunakan oleh industri untuk diambil pati dan dijadikan tepung. Ganyong mengandung pati yang cukup tinggi dan berkualitas baik. Pati ganyong memiliki sifat yang hampir sama dengan tepung tapioka. Pati ganyong dapat digunakan untuk membuat berbagai jenis makanan, seperti kue kering, soun, roti, kerupuk, mie dan makanan bayi (Budiarsih, dkk. 2010; Riskiani dkk., 2014; Hasanah dan Hasrini, 2018).

Pada masyarakat, pembuatan tepung ganyong dilakukan dengan satu kali proses penyaringan, sehingga pati yang terkandung di dalam ampas ganyong masih banyak. Dari 100 kg umbi ganyong yang dihasilkan, diperoleh tepung ganyong sebanyak $16 \mathrm{~kg}$, dan sisanya sekitar $84 \mathrm{~kg}$ adalahampas tepungganyongyang berpotensi sebagai bahan pakan ruminansia. Hasil analisis menunjukkan ampas ganyong mengandung $4,55 \%$ protein kasar; $0,95 \%$ lemak kasar; $19,37 \%$ serat kasar; 4,39\% abu; 70,74\% Bahan Ekstrak Tanpa Nitrogen (BETN) dan 61,35\% Total Digestible Nutrient (TDN). Ampas ganyong dapat dikategorikan sebagai bahan pakan sumber energi (Hartadi dkk., 1991). Tanaman ganyong memiliki senyawa alami yang dapat menghambat pertumbuhan ternak jika diberikan secara berlebihan. Senyawa alami yang terkandung didalamnya adalah saponin (Dewi dan Panunggal., 2016). Kondisi ini yang diduga menjadi pembatas penggunaan ampas ganyong sebagai bahan pakan, akan tetapi jika dilakukan proses fermentasi dapat diamanfaatkan sebanyak 15\% tanpa menganggu performa domba (Wahyuningsih, 2010).

Penelitian ini bertujuan untuk menguji ransum yang mengandung berbagai tingkat penggunaan ampas ganyong terhadap fermentabilitas dan kecernaan secara in vitro.

\section{MATERI DAN METODE}

\section{Ransum Percobaan}

Penelitian menggunakan empat perlakuan ransum sapi penggemukan. Komposisi ransum 
perlakuan terdiri atas hijauan dan konsentrat dengan perbandingan 20:80. Hijauan yang digunakan berupa rumput gajah, sedangkan bahan konsentrat terdiri atas, bungkil kelapa sawit, jagung kuning, onggok, dedak halus, bungkil kelapa, gaplek dan ampas ganyong.
Pengunaan ampas ganyong dalam ransum sebanyak 0\%(R0), 10\% (R1), 20\% (R2) dan 30\% (R3). Susunan dan kandungan nutrien ransum perlakuan disajikan pada Tabel 1. Selanjutnya ransum tersebut dievaluasi secara in vitro (Tilley dan Terry, 1963).

Tabel 1. Susunan bahan pakan dan kandungan nutrien ransum perlakuan.

\begin{tabular}{lcccc}
\hline Bahan Pakan & R0 & R1 & R2 & R3 \\
\hline Rumput Gajah (\%) & 20,00 & 20,00 & 20,00 & 20,00 \\
Konsentrat : & 80,00 & 80,00 & 80,00 & 80,00 \\
Jagung Kuning (\%) & 14,11 & 12,44 & 10,45 & 3,29 \\
Gaplek (\%) & 7,54 & 4,39 & 1,00 & 1,00 \\
Bungkil Kelapa Sawit (\%) & 15,00 & 15,00 & 15,00 & 15,00 \\
Bungkil Kelapa (\%) & 23,70 & 23,90 & 24,43 & 28,71 \\
Onggok (\%) & 6,85 & 3,59 & 1,00 & 1,00 \\
Dedak Halus (\%) & 12,80 & 10,68 & 8,12 & 1,00 \\
Ampas Ganyong (\%) & 0,00 & 10,00 & 20,00 & 30,00 \\
\hline Total & 100,00 & 100,00 & 100,00 & 100,00 \\
\hline Kandungan Zat Makanan & & & & \\
\hline Protein Kasar (\%) & 11,00 & 11,00 & 11,00 & 11,00 \\
Lemak Kasar (\%) & 5,49 & 5,42 & 5,36 & 5,34 \\
Serat Kasar (\%) & 15,52 & 17,28 & 18,00 & 18,27 \\
Bahan Ekstrak Tanpa Nitrogen (BETN) & 60,84 & 59,29 & 58,83 & 59,09 \\
Abu (\%) & 7,15 & 7,01 & 6,81 & 6,30 \\
Total Digestible Nutrient/TDN (\%) & 63,06 & 62,03 & 61,11 & 61,26 \\
\hline Kot & & & \\
\hline
\end{tabular}

Keterangan : Kandungan nutrien ransum perlakuan didasarkan pada perhitungan $100 \%$ bahan kering (BK).

\section{Pelaksanaan In Vitro}

Sampel ditimbang $0,5 \mathrm{~g}$ dan dimasukkan ke dalam tabung fermentor, lalu dimasukan $10 \mathrm{~mL}$ cairan rumen dan $40 \mathrm{~mL}$ larutan saliva buatan (McDaugall) kemudian ditambahkan gas $\mathrm{CO}_{2}$ sambil dikocok agar mencapai suasana anaerob dan $\mathrm{pH}$ 6,5-6,9, lalu ditutup dengan karet berpentil. Tabung dimasukkan ke dalam water bath yang telah diatur suhunya berkisar 39$40^{\circ} \mathrm{C}$. Masing-masing tabung diinkubasi selama 3 dan 48 jam. Tabung yang diinkubasi selama 3 jam dibuka dan ditambahkan $\mathrm{HgCl}_{2}$ jenuh sebanyak 2-3 tetes untuk membunuh mikroba. Cairan dalam tabung diambil dan disentrifuse pada kecepatan $3000 \mathrm{rpm}$ selama 15 menit. Bagian cair (supernatan) cair diambil untuk dianalisis VFA menggunakan metode destilasi uap Markham (University of Wisconsin, 1966) dan sebagian dianalisis $\mathrm{N}-\mathrm{NH}_{3}$ menggunakan metode mikrodifusi cawan Conway yang dijelaskan oleh Hernaman dkk. (2005).

Tabung dengan inkubasi 48 jam dikocok setiap 3 jam sekali, setelah 48 jam ditambahkan $\mathrm{HgCl}_{2}$ sebanyak 2-3 tetes agar mirkoba mati dan kemudian dilakukan sentrifugasi selama 10 menit pada kecepatan $10.000 \mathrm{rpm}$. Bagian cair (supernatan) dipisahkan, sedangkan pada endapan ditambah $5 \mathrm{~mL}$ larutan pepsin 0,2\% dalam suasana asam. Kemudian dikembalikan lagi ke water bath untuk diinkubasi kembali dalam suasana aerob selama 48 jam dan dilakukan pengadukan selama inkubasi. Setelah selesai, terakhir dilakukan analisis kecernaaan bahan kering dan bahan organik dengan metode seperti yang dijelaskan oleh Hernaman dkk. (2005).

\section{Analisis Statistik}

Penelitian menggunakan rancangan acak lengkap dengan 4 perlakuan dan 5 ulangan. Hasil penelitian diuji dengan sidik ragam dan bila terjadi perbedaan nyata dilanjutkan dengan uji Duncan dan untuk mengetahui model hubungan antara VFA dengan kecernaan bahan kering dan kecernaan bahan organik digunakan analisis regresi dan korelasi (Steel dan Torrie, 1993). 


\section{HASIL DAN PEMBAHASAN}

Hasil pengamatan mengenai pengaruh penggunaanampas ganyong terhadap produksi $\mathrm{N}^{-} \mathrm{NH}_{3}$ dan VFA, kecernaan bahan kering dan kecernaan bahan organik disajikan pada Tabel
2. Pada tabel tersebut menunjukkan ampas ganyong dalam ransum tidak berpengaruh nyata pada konsentrasi $\mathrm{N}^{-\mathrm{NH}_{3}}$, namun berpengaruh terhadap penurunan konsentrasi VFA, kecernaan bahan kering dan kecernaan bahan organik.

Tabel 2. Fermentabilitas dan kecernaan in vitro ransum yang mengandung ampas Ganyong.

\begin{tabular}{|c|c|c|c|c|}
\hline Peubah & R0 & R1 & R2 & R3 \\
\hline $\mathrm{N}^{-\mathrm{NH}_{3}}(\mathrm{mM})$ & $7,47 \pm 0,39$ & $8,11 \pm 0,49$ & $7,96 \pm 0,52$ & $7,29 \pm 0,83$ \\
\hline VFA (mM) & $123,60 \pm 4,51^{\mathrm{c}}$ & $127,40 \pm 4,34^{c}$ & $104,00 \pm 4,74^{\mathrm{b}}$ & $77,00 \pm 6,25^{a}$ \\
\hline Kecernaan Bahan Kering (\%) & $56,49 \pm 0,93^{\mathrm{d}}$ & $54,55 \pm 0,74^{c}$ & $52,61 \pm 0,94^{\mathrm{b}}$ & $49,59 \pm 0,72^{a}$ \\
\hline Kecernaaan Bahan Organik (\%) & $54,64 \pm 0,39^{\mathrm{d}}$ & $52,30 \pm 0,91^{\mathrm{c}}$ & $49,05 \pm 0,79^{\mathrm{b}}$ & $46,13 \pm 0,56^{a}$ \\
\hline
\end{tabular}

Amonia $\left(\mathrm{N}_{-} \mathrm{NH}_{3}\right)$ diperoleh dari hasil degradasi protein kasar dalam ransum oleh mikroba yang terdapat dalam cairan rumen. Pada penelitian ini protein kasar pada ransum perlakuan dibuat sama yaitu $11 \%$ (Tabel 1). Hal ini diduga protein ransum memiliki kadar yang rendah, sehingga mikroba rumen akan memaksimalkan nitrogen yang ada. Sumbangan protein ampas ganyong sendiri terhadap ransum sangat rendah, karena bahan pakan tersebut hanya mengandung $4,55 \%$. Kandungan protein ransum yang sama memberikan peluang yang sama bagi mikroba rumen, khususnya bakteri proteolitik untuk memfermentasi menjadi $\mathrm{N}-\mathrm{NH}_{3}$. Produksi $\mathrm{N}-\mathrm{NH}_{3}$ pada penelitian ini berkisar 7,208,11 mM. Produksi $\mathrm{N}^{-\mathrm{NH}_{3}}$ untuk keempat perlakuan semuanya berada dalam kisaran normal karena sesuai dengan pendapat $\mathrm{N}-\mathrm{NH}_{3}$ yang dibutuhkan untuk menunjang kebutuhan mikroba adalah 4-12 mM (Sutardi, 1980). Produksi $\mathrm{N}^{-\mathrm{NH}_{3}}$ dipengaruhi oleh beberapa faktor antara lain : sumber $\mathrm{N}$, solubilitas dan degradasi protein, level $\mathrm{N}$ dalam ransum, waktu setelah pemberian pakan, sumber energi, laju pengosongan rumen, laju penggunaan $\mathrm{N}$ bagi biomassa mikroba rumen dan absorbsi ammonia atau daur ulang urea (Djajanegara, 1979). Produk fermentasi ini akan dimanfaatkan mikroba untuk mensintesis protein mikroba. Menurut McDonald dkk. (2002) produksi $\mathrm{N}-\mathrm{NH}_{3}$ yang optimum akan berakibat pada pertumbuhan mikroba menjadi lebih cepat dan degradasi karbohidrat semakin meningkat. Apabila kadar $\mathrm{N}-\mathrm{NH}_{3}$ melebihi batas optimum, akan mengakibatkan akumulasi di dalam cairan rumen dan akan mengakibatkan keracunan pada ternak tersebut terutama pada ransum yang rendah energi. Rendahnya $\mathrm{N}-\mathrm{NH}_{3}$ akan berakibat negatif terhadap aktivitas mikroba, sintesis protein mikroba dan perkembangan pencernaan, sehingga menurunkan pemasukan energi dan protein (Owens dan Zinn, 1988).

Volatile fatty acid merupakan hasil fermentasi dari karbohidrat dengan produk utamanya berupa asam asetat, butirat dan propionat (Hikmawan dkk., 2019). Volatile fatty acid pada penelitian ini berada pada kisaran 77,00-127,04 mM. Perlakuan R0 dengan R1 tidak berbeda nyata, namun berbeda $(\mathrm{P}<0,05)$ dengan R2 dan R3, sedangkan R2 dan R3 berbeda nyata. Perlakuan P3 memiliki konsentrasi VFA yang paling rendah. Pada perlakuan R3 memiliki konsentrasi VFA yang rendah, karena tidak dalam kisaran normal yang dibutuhkan untuk pertumbuhan mikroba rumen yang optimal 80-160 mM (McDonald dkk. 2002). Pada perlakuan P1, yaitu penggunaan ampas ganyong sebanyak 10\% terjadi peningkatan konsentrasi VFA, meskipun tidak berbeda nyata dengan R0 yaitu penggunaan ampas ganyong sebesar $0 \%$, setelah itu terjadi penurunan secara signifikan $(\mathrm{P}<0,05)$ pada $\mathrm{P} 2$ dan berlanjut pada P3. Penggunaan ampas ganyong sampai batas 10\% tidak menganggu fermentabilitas karbohidrat yang terkandung dalam ampas ganyong menjadi VFA, bahkan relatif lebih tinggi dibandingkan dengan ransum yang tidak menggunakan ampas ganyong. Hal ini karena ampas ganyong mengandung karbohidrat yang mudah dicerna. Proporsi BETN pada ampas ganyong lebih tinggi dibandingkan serat kasar, yaitu $70,74 \%$ vs $19,37 \%$. Menurut Hernaman dkk. (2015) bahwa BETN adalah komponen nutrien dalam analisis proksimat yang diantaranya mengandung pati dan komponen ini lebih mudah difermentasi oleh mikroba rumen dibandingkan dengan serat kasar.

Pemberian ampas ganyong lebih dari $10 \%$ terjadi penurunan konsentrasi VFA. Kondisi ini diduga disebabkan oleh kehadiran senyawa berupa saponin (Dewi dan Panunggal, 2016) 
pada umbi ganyong yang diduga kuat juga terdapat dalam ampas ganyong sebagai bagian dari umbi ganyong. Uji kandungan zat bioaktif menunjukkan adanya senyawa alkaloid, flavonoid, saponin, triterpenoid dan steroid pada umbi ganyong dengan nilai $\mathrm{IC}_{50}$ ekstrak etanol umbi ganyong sebesar 1035,06 g/mL (Hasri, 2016).

Pada penggunaan $10 \%$ ampas ganyong, kehadiran saponin yang terkandung di dalamnya belum mengganggu fermentabilitas karbohidrat ransum, namun penggunaan lebih dari $10 \%$ akan terjadi akumulasi senyawa saponin yang lebih banyak dan tentunya mengganggu fermentabilitas karbohidrat dalam cairan rumen. Penggunaan saponin yang berlebihan dapat berperan sebagai antibakteri dengan mengganggu permeabilitas membran sel bakteri yang menyebabkan keluarnya berbagai komponen penting antara lain protein, asam nukleat, nukleotida dan komponen lainnya (Fahrunisa dan Pratiwi, 2015). Hal ini menyebabkan metabolisme terhambat, sehingga pertumbuhan sel bakteri menjadi terganggu dan menyebabkan kematian sel, sedangkan mikroba rumen terutama bakteri pencerna selulolitik dan amilolitik berperan dalam perombakan karbohidrat ransum menjadi VFA. Saponin juga dapat menganggu perkembangan protozoa dengan terjadinya ikatan antara saponin dengan sterol pada permukaaan membran sel protozoa yang menyebabkan membran sel pecah, sel menjadi lisis dan mati atau defaunasi (Wahyuni dkk., 2014). Hu dkk. (2005) menunjukkan efek penambahan ekstrak saponin $(0,2-0,4 \mathrm{mg} / \mathrm{mL})$ dapat menurunkan populasi protozoa cairan rumen. Protozoa memiliki fungsi yang hampir sama dengan bakteri diantaranya dapat melakukan fermentasi selulosa (Yanuartono dkk., 2019) menjadi VFA, dengan demikian, ketidakhadiran protozoa akibat kehadiran saponin diduga menyebabkan penurunan VFA.

Kecernaan bahan kering menunjukkan penurunan nyata seiring dengan meningkatnya penggunaan ampas ganyong. Hal yang sama juga terjadi pada kecernaan bahan organik. Kecernaan bahan organik pada hakekatnya sama dengan kecernaan bahan kering, hanya pada kecernaan bahan organik tidak memperhitungkan kadar mineral pakan.

Sebagaimana yang telah dibuktikan pada Tabel 2, kehadiran senyawa saponin menyebabkan nilai VFA berkurang. Hal ini mencerminkan karbohidrat (serat kasar+BETN) dalam ransum terlindungi dari degradasi mikroba rumen seiring dengan meningkatnya ampas ganyong yang mengandung senyawa saponin. Karbohidrat dalam penelitian merupakan nutrien yang paling banyak proporsinya (76,36-77,36\%), begitupula pada ampas ganyong juga memiliki proporsi karbohidrat sebanyak 90,11\%. Jika fermentabilitas karbohidrat terganggu yang ditunjukkan dengan produksi VFA, maka akan berpengaruh juga terhadap kecernaan bahan kering dan bahan organik. Hal ini dapat dilihat dengan hubungan antara VFA dengan kecernaan bahan kering dan kecernaan bahan organik (Gambar 1).

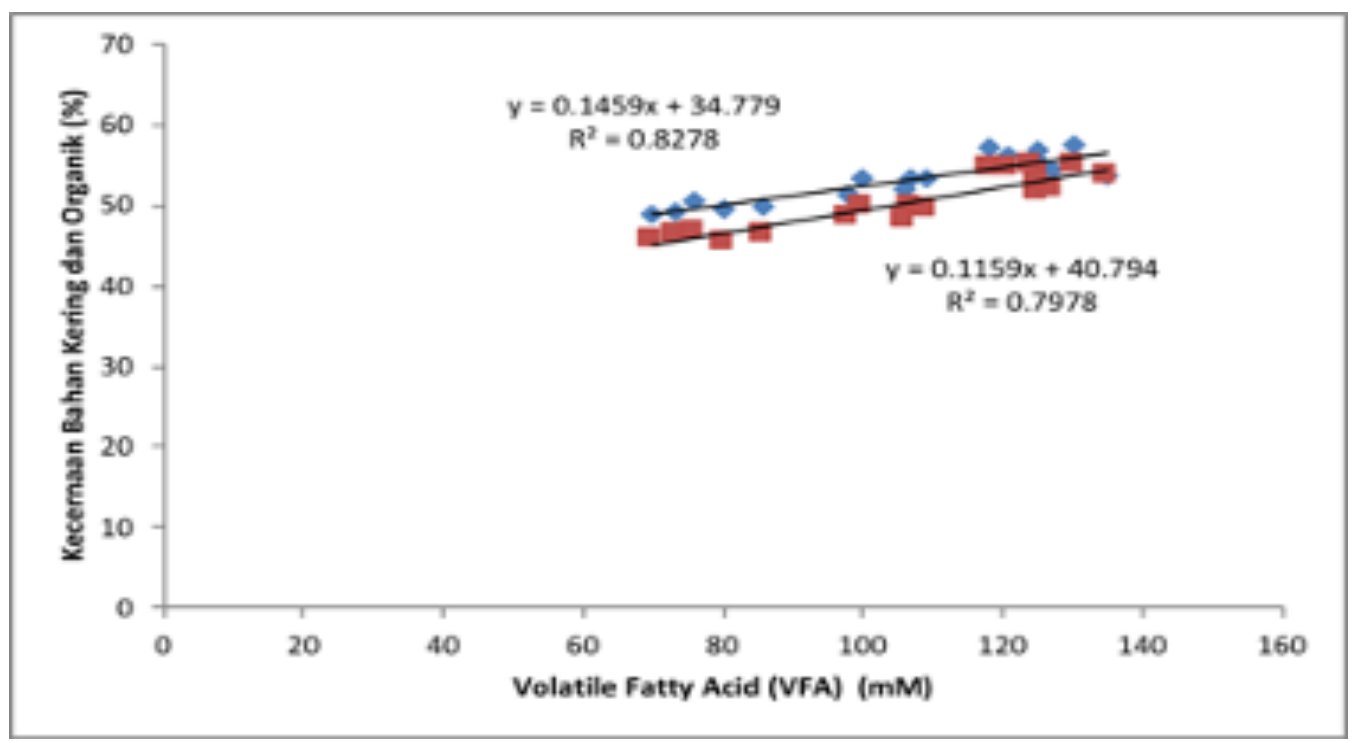

Gambar 1. Hubungan antara VFA dengan kecernaan bahan kering dan bahan organik. 
Hubungan tersebut tampak positif, jika VFA tinggi maka kecernaan bahan kering maupun kecernaan bahan organik juga tinggi. Hubungan tersebut membentuk regresi linear dengan persamaan regresi antara VFA dengan kecernaan bahan kering maupun kecernaan bahan organik adalah: $y=0,1459 x+34,779$ dengan $\mathrm{R}^{2}=0,8278$ dan $\mathrm{y}=0,1159 \mathrm{x}+$ 40,794 dengan $\mathrm{R}^{2}=0,7978$. Nilai keeratan hubungannya secara berturut-turut adalah $r=0,9098$ dan $r=0,8931$. Nilai tersebut menunjukkan adanya hubungan yang sangat erat (Sugiyono, 2007) diantara peubah tersebut. Hal ini berarti adanya hubungan yang sangat erat antara fermentabilitas ransum yang dilihat dari konsentrasi VFA dengan kecernaan bahan kering dan kecernaan bahan organik.

\section{KESIMPULAN}

Pengguanaan ampas ganyong dapat menurunkan produksi VFA, kecernaan bahan kering dan kecernaan bahan organik, namun tidak terhadap $\mathrm{N}-\mathrm{NH}_{3}$. Ampas ganyong dapat digunakan dalam ransum maksimum $10 \%$.

\section{UCAPAN TERIMAKASIH}

Terima kasih pada Kepala dan Teknisi Laboratorium Nutrisi Ternak Ruminansia dan Kimia Makanan Ternak, Fakultas Peternakan Universitas Padjadjaran yang telah membantu dan memberikan fasilitas dalam pelaksanaan penelitian.

\section{DAFTAR PUSTAKA}

Budiarsih, D. R., B. K. Anandito, \& G. Fauza. 2010. Kajian penggunaan tepung ganyong (Canna edulis Kerr.) sebagai substitusi tepung terigu pada pembuatan mie kering. Jurnal Teknologi Hasil Pertanian. 3(2) : 87-94.

Dewi, L. K. \& B. Panunggal. 2016. Analisis kadar saponin dan total bakteri asam laktat pada yogurt ganyong (Canna edulis Kerr.) sinbiotik substitusi kacang merah (Phaseolus vulgaris L.). Journal of Nutrition College. 5(1) : 14-19.

Djajanegara, A. 1979. A Comparison of Techniques of Determining the Amount of By-pass Protein Ruminant. Thesis. Department of Biochemistry and Nutrition.

Fahrunisa. \& R. Pratiwi. 2015. Kandungan Saponin Buah, Daun, dan Tangkai Daun Belimbing Wuluh (Averrhoa bilimbi L.). Seminar Nasional Konservasi dan Pemanfaatan Sumber Daya Alam Universitas Gadjah Mada Yogyakarta. Yogyakarta.
Hasanah, F. \& R. F. Hasrini. 2018. Pemanfaatan ganyong (Canna edulis Kerr.) sebagai bahan baku sohun dan analisis kualitasnya. Journal of Agro-based Industry. 35(2) : 99-105.

Hasri, D. O. 2016. Uji karakteristik amilum dan aktivitas antioksidan umbi ganyong (Canna edulis Kerr.) dengan metode DPPH secara in vitro. Karya Ilmiah. Universitas Esa Unggul. Jakarta.

Hartadi, H., S. Reksodiprodjo, \& A. D. Tillman. 1991. Tabel Komposisi Bahan Makanan Ternak untuk Indonesia. Gadjah Mada University Press. Yogyakarta.

Hernaman, I. U. H. Tanuwiria, \& M. F. Wiyatna. 2005. Pengaruh penggunaan berbagai tingkat kulit kopi dalam ransum penggemukan sapi potong terhadap fermentabilitas rumen dan kecernaan in-vitro. Bionatura. 7: 46-50.

Hernaman, I., A. Budiman, S. Nurochma, dan K. Hidayat. 2015. Kajian in vitro subtitusi konsentrat dengan penggunaan limbah perkebunan singkong yang disuplementasi kobalt (Co) dan seng ( $\mathrm{Zn}$ ) dalam ransum domba. Buletin Peternakan. 39 : 71-77.

Hikmawan, D., Erwanto, Muhtarudin, \& F. Fathul. 2019. Pengaruh substitusi rumput laut (Eucheuma cottonii) dalam pakan rumput gajah (Pennisetum purpureum) terhadap konsentrasi VFA parsial dan estimasi produksi gas metana secara in vitro. Jurnal Riset dan Inovasi Peternakan. 3(1) : 12-18.

Hu, W. L., W. Yue-Ming, L. Jian-Xin, G. Yan-Qiu, \& Y. Jun-An. 2005. Tea saponins affect in vitro fermentation and metanaogenesis in faunated and defaunated rumen fluid. Zhejiang Univ. SCI. 6B: 787-792.

McDonald, P., R. A. Edwards, J. F. D. Greenhalgh, \& C. A. Morgan. 2002. Animal Nutrition $6^{\text {th }} \mathrm{Ed}$. Ashford Colour Pr. Gosport.

Owens, F. N. \& R. A. Zinn. 1988. Protein Metabolism of Ruminant Animals, in The Ruminant Animal Digestive Physiology and Nutrition. Prentice-Hall, Inc., Englewood Cliffs, NJ. Pp 227-249.

Riskiani, D., D. Ishartani, \& D. Rachmawanti. 2014. Pemanfaatan tepung umbi ganyong (Canna edulis Kerr.) sebagai pengganti tepung terigu dalam pembuatan biskuit tinggi energi protein dengan penambahan tepung kacang merah (Phaseolus vulgaris L.) Jurnal Teknosains Pangan. 3(1) : 96-105.

Sugiyono. 2007. Metode Penelitian Pendidikan Pendekatan Kuantitatif, Kualitatif, dan R\&D. Alfabeta. Bandung.

Steel, R. G. D. \& J. H. Torrie. 1993. Prinsip dan Prosedur Statistika. Edisi Kedua. Diterjemahkan oleh B. Sumantri. PT Gramedia Pustaka, Jakarta.

Sutardi, T. 1980. Peningkatan Mutu Hasil Limbah Lignoselulosa sebagai Makanan Ternak. Fakultas Peternakan Institut Pertanian Bogor. Bogor. 
Tilley, J. M. A. \& R. A. Terry. 1963. A two stage technique for the in vitro digestion of the forage crops. J. Brit. Grassl. Soc. 18(2) : 104-106.

University of Wisconsin. 1966. General Laboratory Procedure. Departement of Dairy Science. Medison.

Wahyuningsih, N. 2010. Pengaruh penggunaan ampas ganyong (Canna edulis Kerr.) fermentasi dalam ransum terhadap performan domba lokal jantan. Karya Ilmiah. Universitas Sebelas Maret. Solo.
Wahyuni, I. M. D., A. Muktiani, \& M. Christianto. 2014. Penentuan dosis tanin dan saponin untuk defaunasi dan peningkatan fermentabilitas pakan. JITP. 3(3) : 133-140.

Yanuartono, A. Nururrozi, S. Indarjulianto, \& H. Purnamaningsih. 2019. Peran protozoa pada pencernaan ruminansia dan dampak terhadap lingkungan. Ternak Tropika. 20(1) : 16-28. 